\title{
Front Matter: Volume 11474
}

, "Front Matter: Volume 11474," Proc. SPIE 11474, Organic, Hybrid, and Perovskite Photovoltaics XXI, 1147401 (8 September 2020); doi:

10.1117/12.2581636

SPIE. Event: SPIE Organic Photonics + Electronics, 2020, Online Only 


\section{PRO CEEDINGS OF SPIE}

\section{Organic, Hybrid, and Perovskite Photovoltaics XXI}

Zakya H. Kafafi

Paul A. Lane

Kwanghee Lee

Harald W. Ade

Yueh-lin (Lynn) Loo

Editors

24 August - 4 September 2020

Online Only, United States

Sponsored and Published by

SPIE

Volume 11474 
The papers in this volume were part of the technical conference cited on the cover and title page. Papers were selected and subject to review by the editors and conference program committee. Some conference presentations may not be available for publication. Additional papers and presentation recordings may be available online in the SPIE Digital Library at SPIEDigita lLibra ry.org.

The papers reflect the work and thoughts of the authors and are published herein as submitted. The publisher is not responsible for the validity of the information or for any outcomes resulting from reliance thereon.

Please use the following format to cite material from these proceedings:

Author(s), "Title of Paper," in Organic, Hybrid, and Perovskite Photovolta ics XXI, edited by Zakya H. Kafafi, Paul A. Lane, Kwanghee Lee, Harald W. Ade, Yueh-Lin (Lynn) Loo, Proceedings of SPIE Vol. 11474 (SPIE, Bellingham, WA, 2020) Seven-digit Artic le CID Number.

ISSN: 0277-786X

ISSN: 1996-756X (electronic)

ISBN: 9781510637542

ISBN: 9781510637559 (electronic)

Published by

SPIE

P.O. Box 10, Belling ham, Washington 98227-0010 USA

Telephone +1 3606763290 (Pacific Time)· Fax +1 3606471445

SPIE.org

Copyright (c)2020, Soc iety of Photo-Optic al Instrumentation Engineers.

Copying of material in this book for intemal or personal use, or for the intemal or personal use of specific clients, beyond the fair use provisions granted by the U.S. Copyright Law is authorized by SPIE subject to payment of copying fees. The Transactional Reporting Service base fee for this volume is $\$ 21.00$ per article (or portion thereof), which should be paid directly to the Copyright Clearance Center (CCC), 222 Rosewood Drive, Danvers, MA 01923. Payment may also be made electronically through CCC Online at copyright.com. Other copying for republication, resale, advertising or promotion, or any form of systematic or multiple reproduction of any material in this book is prohibited except with permission in writing from the publisher. The CCC fee code is 0277$786 \times / 20 / \$ 21.00$.

Printed in the United States of Americ a by Curran Associates, Inc., under license from SPIE.

Public ation of record for individual papers is online in the SPIE Digital Library.

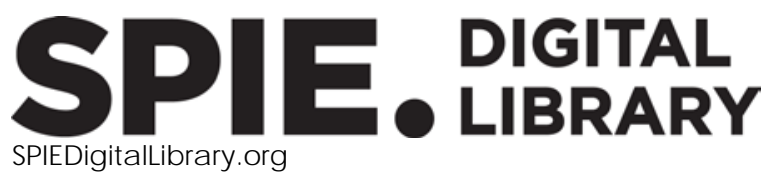

Paper Numbering: Proceedings of SPIE follow an e-First publication model. A unique citation identifier (CID) number is assigned to each article at the time of publication. Utilization of CIDs allows articles to be fully citable as soon as they are published online, and connects the same identifier to all online and print versions of the publication. SPIE uses a seven-digit CID article numbering system structured as follows:

- The first five digits correspond to the SPIE volume number.

- The last two digits indicate publication order within the volume using a Base 36 numbering system employing both numerals and letters. These two-number sets start with $00,01,02,03,04$, 05, 06, 07, 08, 09, 0A, 0B ... 0Z, followed by 10-1Z, 20-2Z, etc. The CID Number appears on each page of the manuscript. 


\section{Contents}

THERMAL MANAGEMENTAND STABIUTY OF PEROVSKTIE SOLAR CEUS: JOINTSESSON WTH 11474 AND 11496

$11474 \mathrm{OK} \quad$ Multi stage and illumination dependent segregation in $\mathrm{MAPb}(\mathrm{I}, \mathrm{Br})_{3}[11474-17]$

NOVE MATERIALS AND FABRICATION TECHNIQUES FOR HIGH PERFORMANCE PEROVSKITE SOLAR CEUS

11474 OW Scaling organic photovoltaics to pilot line fabrication [11474-73]

NOVEL CONCEPIS AND STRUCTURES FOR ORGANIC AND HYBRID PHOTOVOLTAICS

11474 OY Record 1-micron thick QD film photodetectors using intercalated graphene electrodes for high responsivity in the infrared (Invited Paper) [11474-30]

MORPHOLOGY AND NANOSTRUCTURE OFORGANIC AND PEROVSKIIE SOLAR CEUS

1147412 Synchrotron and optical probing of mixed lead halide perovskites for photovoltaics (Invited Paper) [11474-34]

\section{POSTER SESSION}

1147418 Low temperature aggregation transitions in N3 and Y6 acceptors enable double-annealing method that yields hierarchical morphology and superior efficiency in nonfullerene organic solarcells [11474-10]

1147410 In-situ testing of organic photovoltaic (OPV) modules to examine modes of degradation in an arid-hot climate [11474-53]

11474 IP Study the effect of fullerene denivatives ratio on P3HT-based inverted organic solar cells [11474-54]

1147424 Investigating parasitic resistance of mesoporous-based solar cells with respect to thin-film and conventional solar cells [11474-71] 
Proc. of SPIE Vol. 11474 1147401-4

\section{Downloaded From: https://www.spiedigitallibrary.org/conference-proceedings-of-spie on 26 Apr 2023
Terms of Use: https://www.spiedigitallibrary.org/terms-of-use}

